\title{
Comparative study of efficacy of excimer light therapy vs. intralesional triamcinolone vs. topical $5 \%$ minoxidil for alopecia areata: an observational study
}

\author{
Skuteczność światła ekscymerowego, doogniskowego triamcynolonu i miejscowego \\ minoksydylu w alopecia areata - badania porównawcze
}

Zo Nun Sanga

Department of Dermatology, Venereology and Leprosy, Rabindranath Tagore Medical College, Udaipur, Rajasthan, India

Przegl Dermatol 2015, 102, 206-210

DOI: $10.51 \mid 4 / \mathrm{dr} .2015 .51921$

KEY WORDS:

alopecia areata, minoxidil, triamcinolone, excimer light therapy.

\section{SŁOWA KLUCZOWE:}

łysienie plackowate, minoksydyl, triamcynolon, terapia światłem ekscymerowym.

\section{ABSTRACT}

Introduction. Alopecia areata (AA) is a chronic inflammatory disease that involves hair follicles, and sometimes nails, caused by a T-cell mediated autoimmune mechanism. Current treatment modalities include corticosteroids (oral, topical or intralesional), minoxidil, contact sensitizers (DNCB, DPCP and SADBE), immunosuppressants (methotrexate or azathioprine), DMARDs (sulfasalazine), and phototherapy.

Objective. To compare the efficacy of excimer light therapy, intralesional triamcinolone and $5 \%$ topical minoxidil.

Material and methods. After taking consent, 40 patients were treated with excimer light, 46 patients with intralesional triamcinolone injection and 14 patients with $5 \%$ topical minoxidil. The results were compared by their photographs taken prior to treatment, at 2 months and 6 months of follow-up.

Results. Among the excimer group, 21/32 (61.76\%) patients with a single patch and $1 / 6(16.67 \%)$ with multiple patches achieved $>50 \%$ hair regrowth. In the triamcinolone group, 23/30 (76.67\%) with a single patch and $10 / 16(62.5 \%)$ with multiple patches achieved $>50 \%$ hair regrowth, and in the minoxidil group, $4 / 12$ (33.33\%) with a single patch and none, i.e. $0 / 2$, with multiple patches achieved $>50 \%$ regrowth.

Conclusions. After comparing the efficacy of excimer light therapy, intralesional triamcinolone and 5\% minoxidil, it was concluded that intralesional triamcinolone seems to be the most efficacious. Multiple AA patches were more resistant than a single patch. Scalp response was much better than beard.

\section{STRESZCZENIE}

ADDRESS FOR CORRESPONDENCE: Dr Zo Nun Sanga

Department of Skin and VD

BG Hospital

RNT Medical College

313001 Udaipur, India

phone: +8875239908

e-mail: jrkos04@gmail.com
Wprowadzenie. Alopecia areata (AA) jest przewlekłą chorobą zapalną dotyczącą mieszków włosowych i czasami paznokci, wywołaną procesami autoimmunologicznymi mediowanymi przez limfocyty T. Obecnie stosuje się następujące metody terapeutyczne: glikokortykosteroidy podawane ogólnie lub doogniskowo oraz stosowane miejscowo, minoksydyl, substancje uczulające kontaktowo (DNCB, DPCP, SADBE), leki immunosupresyjne (metotreksat, azatiopryna), leki modyfikujące choroby reumatyczne (sulfasalazyna) oraz fotototerapię. 
Cel pracy. Porównanie skuteczności światła ekscymerowego 308 nm, podawanego doogniskowo triamcynolonu oraz stosowanego miejscowo minoksydylu w leczeniu AA.

Materiał i metodyka. W badaniu wzięło udział 40 pacjentów leczonych światłem ekscymerowym, 46 pacjentów, którym podawano doogniskowo triamcynolon, oraz 14 pacjentów leczonych miejscowo 5\% minoksydylem. Wyniki terapii oceniano na podstawie dokumentacji fotograficznej wykonanej w czasie pierwszej wizyty (przed leczeniem) oraz w ciągu 2 i 6 miesięcy po zakończeniu terapii.

Wyniki. W grupie osób leczonych światłem ekscymerowym u 21 pacjentów spośród 32 (61,76\%) z pojedynczymi oraz u 1 spośród 6 z licznymi ogniskami AA obserwowano odrost włosów ponad 50\%. W grupie chorych, której podawano triamcynolon, podobny wynik terapeutyczny uzyskano u 23 spośród 30 (76,67\%) leczonych ze zmianami pojedynczymi i u 10 spośród 16 (62,5\%) z licznymi ogniskami, natomiast $\mathrm{u}$ pacjentów stosujących miejscowo minoksydyl dobry wynik leczenia (> 50\% odrostu) stwierdzono u 4 spośród 12 (33,3\%) chorych z ogniskami pojedynczymi. U żadnego z pacjentów leczonych minoksydylem z licznymi zmianami nie odnotowano zadowalającego odrostu włosów.

Wnioski. Porównanie wyników leczenia AA światłem ekscymerowym, triamcynolonem i minoksydylem wskazuje, że najskuteczniejszą metodą terapeutyczną wydaje się podawany doogniskowo triamcynolon. Liczne ogniska AA oraz zmiany zlokalizowane poza skórą owłosioną głowy są bardziej oporne na stosowane terapie.

\section{INTRODUCTION}

Alopecia areata (AA) is a chronic inflammatory disease that involves hair follicles, and sometimes nails, caused by a T-cell mediated autoimmune mechanism. It is the most common hair loss after androgenic alopecia. It affects all ages, predominantly the $2^{\text {nd }}$ to $4^{\text {th }}$ decade, and both sexes equally [1]. It is a non-scarring telogenic alopecia, predisposed by HLAs such as DQ3, DQ7, DR4 and DR11, CD4+ T helper cells, and is associated, in some patients, with thyroid dysfunctions, psychological problems, atopy, pernicious anemia, and infections [2]. A strong association between autoimmune polyglandular syndrome type 1 (APS1), caused by mutations in the 7 AIRE gene on chromosome 21, and AA has also been reported [3].

Alopecia areata can also present a demarcated patch of hair loss, multiple patches, or extensive hair loss as in alopecia totalis/universalis [3]. It causes significant cosmetic and psychological distress in most of the people it affects.

Current treatment modalities include corticosteroids (oral, topical or intralesional), minoxidil, contact sensitizers (DNCB, DPCP and SADBE), immunosuppressants (methotrexate or azathioprine), DMARDs (sulfasalazine), and phototherapy [4-6].

\section{OBJECTIVE}

The aim of the study was to compare the efficacy of excimer light therapy, intralesional triamcinolone and $5 \%$ topical minoxidil.

\section{MATERIAL AND METHODS}

This was an observational study which was done at the Department of Dermatology, RNT Medical College, Udaipur, Rajasthan, between June 2013 and September 2014. For the purpose of easy comparison and segregation of data, the following inclusion and exclusion criteria were followed.

Inclusion criteria: patients who give consent for the study; patients presenting with alopecia areata (1 to 6 patch/patches, sizes $2 \mathrm{~cm}$ to $10 \mathrm{~cm}$ ), lasting at least 3 months, with no evidence of hair regrowth, with no history of photosensitivity and who have never undergone treatment before, or who have not undergone any treatment for at least 8 weeks; patients who were willing and capable of cooperating to the extent and degree required by the protocol.

Exclusion criteria: patients who do not give consent; patients who received treatment for alopecia areata within the past 8 weeks; patients with alopecia totalis or alopecia universalis; patients with 
Table I. Results of treatment in relation to number of lesions Tabela I. Wyniki leczenia w zależności od liczby ognisk $A A$

\begin{tabular}{lcc} 
Mode of treatment & \multicolumn{2}{c}{$>50 \%$ hair regrowth } \\
\cline { 2 - 3 } & Single patch & Multiple patches \\
\hline Excimer light & $21 / 34(61.76 \%)$ & $1 / 6(16.67 \%)$ \\
\hline Intralesional triamcinolone & $23 / 30(76.67 \%)$ & $10 / 16(62.5 \%)$ \\
\hline Topical minoxidil & $4 / 12(33.33 \%)$ & $0 / 2$ \\
\hline
\end{tabular}

known photosensitivity (polymorphous light eruption, connective tissue diseases, porphyria or xeroderma pigmentosum); pregnant or breast-feeding women; patients with a history of previous skin cancer.

A total of 100 patients were included in the study: 40 patients in the excimer light therapy group, 46 in the triamcinolone group, and 14 in the minoxidil group.

Patients in the excimer light therapy group were given the treatment twice a week, but not on consecutive days. The therapy was started at $300 \mathrm{~mJ} / \mathrm{cm}^{2}$, and it was increased by $100 \mathrm{~mJ} / \mathrm{cm}^{2}$ every visit. If erythema persisted for more than 2 days, the treatment was skipped until erythema was healed and the previous dose was restarted. The end point was either 16 sittings or hair growth, whichever was earlier. Those in the triamcinolone group were given intralesionally triamcinolone $5 \mathrm{mg} / \mathrm{ml}$ every 3 weeks, and patients in the minoxidil group were given $5 \%$ topi- cal minoxidil and were advised to apply, twice a day, $1 \mathrm{ml}$ on each patch.

Photographs taken at the first visit (prior to treatment), after 2 months and then after 6 months were compared. Those patients who achieved $>50 \%$ hair regrowth were considered to have undergone successful therapy.

\section{RESULTS}

In the excimer group, $21 / 32(61.76 \%)$ patients with a single patch and $1 / 6(16.67 \%)$ with multiple patches achieved $>50 \%$ hair regrowth (Table 1, Fig. 1 A-C). In the triamcinolone group, $23 / 30(76.67 \%)$ with a single patch and 10/16 (62.5\%) with multiple patches achieved $>50 \%$ hair regrowth (Table 1), and in the minoxidil group, 4/12 (33.33\%) patients with a single patch and none, i.e. $0 / 2$, with multiple patches achieved $>50 \%$ regrowth (Table 1, Fig. 2 A-C). Regarding the sites of involvement, among those patients who achieved $>50 \%$ hair regrowth, 22/32 (68.75\%) treated with excimer light had a single patch and 1/6 (16.67\%) had multiple patches on the scalp (Table 2), in the triamcinolone group, 22/25 (88\%) had a single patch on the scalp, $8 / 10(80 \%)$ had multiple patches on the scalp, $1 / 5(20 \%)$ had a single patch and $2 / 6(33.33 \%)$ had multiple patches on the beard (Table 2, Fig. 2 A-C), and in the minoxidil group, 4/10 (40\%) with a single patch on the scalp and none with multiple patches achieved successful results (Table 2, Fig. 3 A-C).
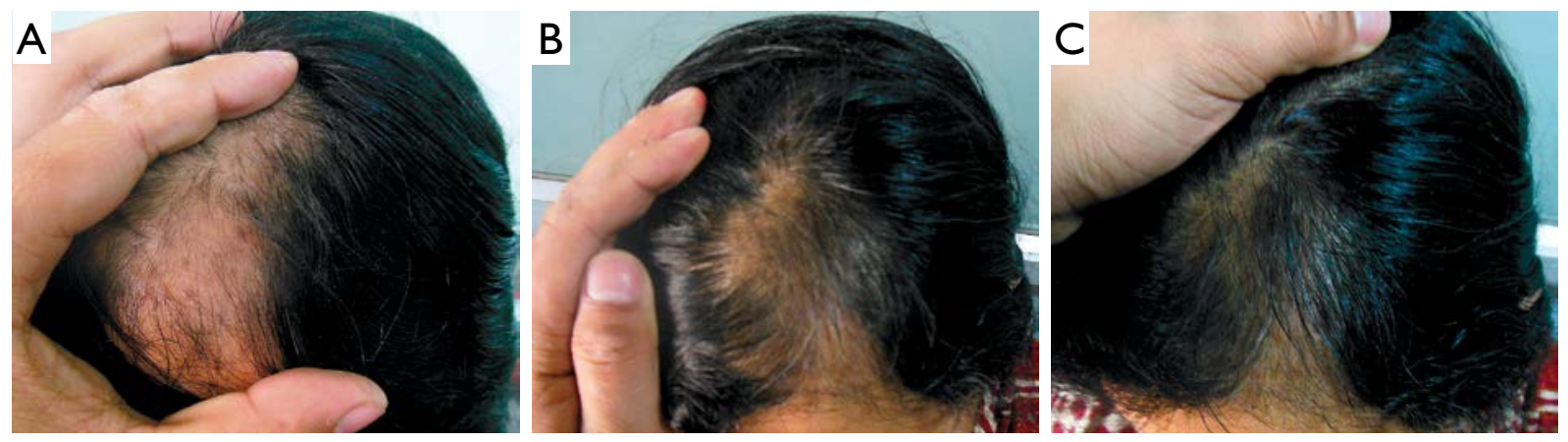

Figure I. Excimer light: A - pre-treatment, B - after 2 months, C - after 6 months

Rycina I. Leczenie świattem ekscymerowym: A - przed leczeniem, $\mathbf{B}$ - 2 miesiq̨ce po terapii, $\mathbf{C}$ - po 6 miesiq̨cach
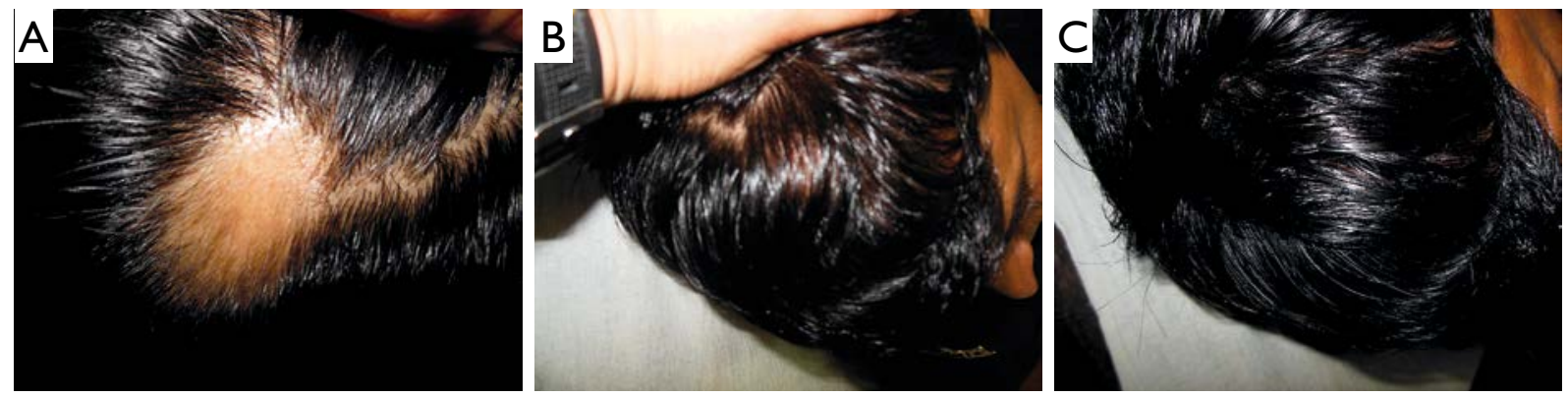

Figure 2. Intralesional triamcinolone: A - pre-treatment, B - partial regrowth after 2 months, $\mathbf{C}$ - complete regrowth after 6 months Rycina 2. Leczenie doogniskowym triamcynolonem: $\mathbf{A}$ - przed leczeniem, $\mathbf{B}-2$ miesiqce po terapii, $\mathbf{C}$ - po 6 miesiq̨cach 
Table 2. Results of treatment in relation to localization of AA patches

Tabela 2. Wyniki leczenia w zależności od lokalizacji ognisk AA

\begin{tabular}{|c|c|c|c|c|c|}
\hline \multirow{3}{*}{$\begin{array}{l}\text { Mode of } \\
\text { treatment }\end{array}$} & \multicolumn{5}{|c|}{$>50 \%$ hair regrowth } \\
\hline & \multicolumn{2}{|c|}{ Scalp } & \multicolumn{2}{|c|}{ Beard } & \multirow{2}{*}{$\begin{array}{l}\text { Patches in both } \\
\text { sites }\end{array}$} \\
\hline & Single patch & Multiple patches & Single patch & Multiple patches & \\
\hline Excimer & $22 / 32(68.75 \%)$ & $1 / 6(16.67 \%)$ & $0 / 7$ & 0 & $0 / 1$ \\
\hline Triamcinolone & $22 / 25$ (88\%) & $8 / 10(80 \%)$ & I/5 (20\%) & $2 / 6(33.33 \%)$ & 0 \\
\hline Minoxidil & $4 / 10(40 \%)$ & $0 / 1$ & $0 / 2$ & $0 / 1$ & 0 \\
\hline
\end{tabular}

\section{DISCUSSION}

Alopecia areata (AA) is a non-scarring, autoimmune, inflammatory, relapsing hair loss condition affecting the scalp and/or body. It is also known as pelade, or area celsi. It commonly manifests as a sudden loss of hair in localized areas. In the acute phase of AA, CD4+ and CD8+ T cells infiltrate the juxta-follicular area. In the chronic phase of AACD8+ T cells dominate in the infiltrate around hair bulbs, which contributes to the prolonged hair loss. It is postulated that the characteristic T cell "swarm of bees" infiltrate seen in alopecia areata is the result of $\mathrm{T}$ cells attracted to the hair follicle by NKG2D-activating ligands.

Intralesional triamcinolone acetonide is a safe and effective treatment for patients with extensive alopecia areata. Patients with exclamation point hairs and a positive hair pull test may be more likely to respond [7]. Triamcinolone acetonide is used most commonly with concentrations varying from $2.5 \mathrm{mg} / \mathrm{ml}$ to $10 \mathrm{mg} / \mathrm{ml}$, the lowest concentration being used on the face. A concentration of $5 \mathrm{mg} / \mathrm{ml}$ is usually sufficient on the scalp. Less than $0.1 \mathrm{ml}$ is injected per site, with approximately $1 \mathrm{~cm}$ between injection sites. It is mainly used for its immunosuppressive effects.

The hair growth stimulating effect of minoxidil is linked to stimulation of PGE2 synthesis by activating prostaglandin-H synthase (PGHS)-1. Normally, calcium influx enhances epidermal growth factors to inhibit hair growth. Minoxidil is converted to minoxidil sulfate, which is a potassium channel agonist and enhances potassium ion permeability, thus opposing the entry of calcium into cells. It also seems to have a direct mitogenic effect on epidermal cells, and also prolongs the survival time of keratinocytes [8].

The biologic events by which laser and light sources produce hair growth are unclear. Hypertrichosis is the result of follicles converting from telogen (the resting phase) to anagen (the active phase), or vellus follicles transforming into terminal follicles. Sunlight has been recognized as a promoter of hypertrichosis. Although the pathogenesis is unknown, evidence shows that UV radiation may upregulate production of prostaglandin E2, an inflammatory mediator that is known to induce reversible eyelid hypertrichosis and to stimulate hair growth when applied topically in animal models [9].

A study conducted on the efficacy of a 308-nm excimer lamp for the treatment of alopecia areata by Ohtsuki et al. showed that 4/16 (57\%) patients with single AA who completed the study showed regrowth involving more than 50\% [10]. Hair regrowth was documented in $86 \%$ of single AA patients. Six $(67 \%)$ patients with multiple patches showed regrowth involving more than $50 \%$ of lesional areas, while two $(22 \%)$ showed regrowth involving less than $50 \%$ of lesional areas [10]. In another study on the treatment of 42 AA patches with the $308 \mathrm{~nm}$ excimer laser, hair regrowth was observed in $41.5 \%$ of treated areas [11]. Hair regrowth was noticed to begin to appear during the second month of therapy. No regrowth of hair was noted on the control patch-
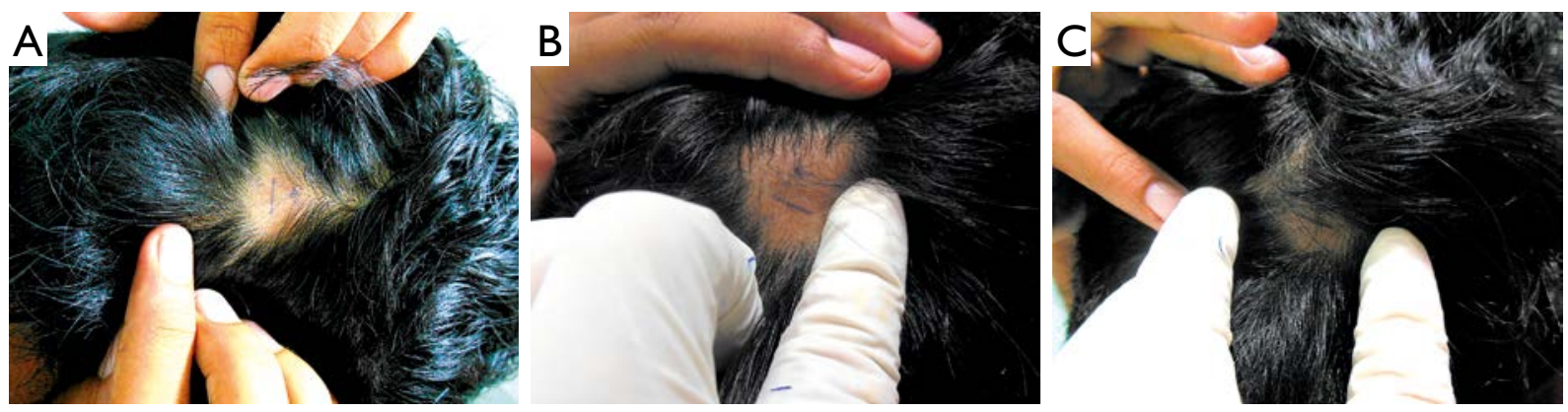

Figure 3. Minoxidil group: A - pre-treatment, B - after 2 months, $\mathbf{C}$ - after 6 months

Rycina 3. Leczenie minoksydylem: $\mathbf{A}$ - przed leczeniem, $\boldsymbol{B}-2$ miesiq̨ce po terapii, $\boldsymbol{C}$ - po 6 miesiq̨cach 
es. Laser therapy was administered twice a week for a maximum of 24 sessions. Apart from erythema at the treated sites, there were no significant adverse effects. Relapses of alopecia areata were observed in two patients with patchy alopecia areata of the scalp who had shown complete regrowth earlier [11].

In our study, $21 / 32(61.76 \%)$ patients with a single patch and $1 / 6(16.67 \%)$ with multiple patches achieved $>50 \%$ hair regrowth (Table 1$)$. Ganjoo and Thappa [12] conducted a study on 70 patches in 60 patients with alopecia areata, which were injected with corticosteroids at a 4-week interval, followed up for 24 weeks and evaluated using a regrowth scale (RGS). The Heine DELTA 20 dermatoscope was used to assess disease activity, response to treatment and side effects. Twenty-eight patients responded early and achieved RGS of 4 within 12 weeks, 29 patients responded late and achieved RGS of 4 within 24 weeks, and 3 patients did not achieve RGS of 4 at 24 weeks. Late and incomplete responders showed a statistically significant association with family history of alopecia areata $(p<0.0001)$, presence of recurrent disease $(p=0.0147)$ and presence of nail changes $(p=0.0007)$. Dermoscopically, 60 patches demonstrated regrowth of new vellus hair at 4 weeks. Tapering hair disappeared maximally at 4 weeks. At 12 weeks, complete disappearance was seen in tapering hairs, broken hairs and black dots, whereas for yellow dots to disappear completely in all patches it took 16 weeks [12], while in our study, $23 / 30(76.67 \%)$ with a single patch and $10 / 16(62.5 \%)$ with multiple patches achieved $>50 \%$ hair regrowth.

According to Alsantali [8], in a placebo-controlled, double-blind study, hair regrowth was observed in $63.6 \%$ and $35.7 \%$ of minoxidil-treated and placebo groups, respectively. However, only $27 \%$ of minoxidil-treated patients showed cosmetically acceptable hair regrowth. In another study, hair regrowth was achieved in $38 \%$ and $81 \%$ of patients treated with $1 \%$ and 5\% topical minoxidil, respectively. Most studies have shown no beneficial effect of topical minoxidil in alopecia totalis and alopecia universalis. Minoxidil $5 \%$ solution or foam is frequently used with other therapeutic agents as an adjuvant therapy. The adverse effects of topical minoxidil include contact dermatitis and facial hypertrichosis, while in our study, $4 / 12(33.33 \%)$ with a single patch and none with multiple patches achieved $>50 \%$ regrowth.
There were some limitations of this study. Firstly, it was not a blinded, controlled study. Also, the effect of duration of the disease and co-morbidities (which could influence the response to treatment) were not taken into consideration.

\section{CONCLUSIONS}

Although all three modalities of treatment are useful for therapy of alopecia areata, intralesional triamcinolone seems to be the most efficacious. Multiple patches were more resistant than a single patch. Scalp response is much better than beard, the reason requiring further investigation.

\section{Conflict of interest}

The author declares no conflict of interest.

\section{References}

1. Mehta B.A., Raka A., Bharmbhatt V.: Comparative study of various regimens in alopecia areata. Internet J Dermatol $2012,9,1$.

2. Galan-Gutierrez M., Rodriguez-Bujaldon A., Moreno-Gimenez J.C.: Update on the treatment of alopecia areata. Actas Dermosifiliogr 2009, 100, 266-276.

3. Ito T., Tokura Y.: The role of cytokines and chemokines in the $\mathrm{T}$ cell-mediated autoimmune process in alopecia areata. Exp Dermatol 2014, 23, 787-791.

4. Aubin F., Vigan M., Puzenat E., Blanc D., Drobacheff C., Deprez P., et al.: Evaluation of a novel $308 \mathrm{~nm}$ monochromatic excimer light system in dermatology: a pilot study in different chronic localised dermatoses. Br J Dermatol 2005, 152, 99-103.

5. Sand G., Messenger A.G.: Alopecia areata. Evidence based treatment. Semin Cutan Med Surg 2009, 28, 15-18.

6. Wasserman D., Guzman-Sanchez D.A., Scott K., McMichael A.: Alopecia areata. Int J Dermatol 2007, 46, 121-131.

7. Chang K.H., Rojhirunsakool S., Goldberg L.J.: Treatment of severe alopecia areata with intralesional steroid injections. J Drugs Dermatol 2009, 8, 909-912.

8. Alsantali A.: Alopecia areata: a new treatment pan. Clin Cosmet Invest Dermatol 2011, 4, 107-115.

9. Rangwala S.., Rashid A.M.: Alopecia: a review of laser and light therapies. Dermatol Online J 2012, 18, 3.

10. Ohtsuki A., Hasegawa T., Komiyama E., Takagi A., Kawasaki J., Ikeda S.: 308-nm excimer lamp for the treatment of alopecia areata: clinical trial on 16 cases. Indian J Dermatol 2013, 58, 326.

11. Al-Mutairi N.: 308-nm excimer laser for the treatment of alopecia areata. Dermatol Surg 2007, 33, 1483-1487.

12. Ganjoo S., Thappa D.M.: Dermoscopic evaluation of therapeutic response to an intralesional corticosteroid in the treatment of alopecia areata. Indian J Dermatol Venereol Leprol 2013, 79, 408-417. 